\title{
Relevant Education for Sustainable Human Development in Nigeria: Nollywood's Advocacy in Selected Video Films
}

\author{
Chisimdi Udoka Ihentuge \& Maudlyn Oghenesuvwe Ejogharado \\ http://dx.doi./org/10.4314/ujah.v18i2.7
}

\section{Abstract}

In human development, conscious efforts are made to enlarge people's choices to enable them live a healthy and prolonged life, acquire knowledge, and have access to resources needed to earn a decent living. Obviously, sustained improvement in African human development still falls short of those experienced in other regions. Progress in African human development is majorly driven by education as against the experience of other regions where other factors dominate. Nollywood, the Nigerian video film industry, has played an active role in advocating the need for relevant education for all ages in Nigeria. This work attempts a discussion of Nollywood's education advocacy for sustainable human development through the reading of selected films. The concept development communication is relied on for conceptual foundation; while the theory of knowledge gap hypothesis is adopted for theoretical backing. The methodology adopted involves documentary research and extensive viewing of relevant films which culminated in content analysis of the viewed films. It is observed that Nollywood has not performed so poorly in advocating education as the major sign post for human development in Nigeria. Yet, a lot more still need to be done. It is recommended that Nollywood filmmakers pay serious attention to the sociology of their craft. Government and the educational sector should sponsor educational films through concept placement options. The general public, particularly the academe, should see 
and explore the positive aspect of Nollywood rather than continue to treat the industry with contempt as was the case with the Onitsha market literature - the consequence of which we are still facing.

\section{Introduction}

Human development was originally defined as "a process of enlarging people's choices" that enables them "to lead a long and healthy life, to acquire knowledge and to have access to resources needed for a decent standard of living ... (EHES, 2).

The above view by the European Historical Economics Society (EHES), which is cited from the United Nations Development Program (UNDP) Human Development Report (1990), seems a safe haven to begin this discourse. Also, Sabina Alkire quotes the same United Nations Development Program (UNDP) Human Development Report (1990) as giving a more simple explanation of human development thus:

People are the real wealth of a nation. The basic objective of development is to create an enabling environment for people to live long, healthy and creative lives. This may appear to be a simple truth. But it is often forgotten in the immediate concern with the accumulation of commodities and financial wealth (2).

The views above are not in any way novel. It could be rightly said that very many ancient thinkers had captured these in their writings. The full definition of human development as captured still in the Human Development Report (1990) is much more encompassing as it is simplistic. It states that: 
Human development is a process of enlarging people's choices. The most critical ones are to lead a long and healthy life, to be educated and to enjoy a decent standard of living. Additional choices include political freedom, guaranteed human rights and self-respect - what Adam Smith called the ability to mix with others without being "ashamed to appear in public (quoted in Alkire, 2).

Hence, this work is in total agreement with Alkire in the use of the term human development. To Alkire,

The term human development here denotes both the process of widening people's choices and the level of their achieved well-being. It also helps to distinguish clearly between two sides of human development. One is the formation of human capabilities, such as improved health or knowledge. The other is the use that people make of their acquired capabilities, for work or leisure (3).

Education is literally defined as a process of impacting or acquiring general knowledge. Ivowi (1) states that "education in terms of schooling, vocational training and life-long learning is aimed at developing the individual and society at large". This explains that education is not only meant for the development of an individual but also for the development of the society. J Ahenta posits that "education is a tool of a process by which a person develops abilities, attitude, and other forms of behaviour of positive value in the society" (9). This process can be through formal schooling which now claims a lion's share of the responsibility for educating the members of the society. Education is acquired through formal, non-formal and informal ways. Curle (1970) is quoted in Aghenta (9) as stating thus: 
In order to develop, a country must have a very considerable proportion of trained educated citizens not only to act as doctors, engineers etc but must create a new class sufficiently large and hence sufficiently strong, to establish its own values of justice...

Education not only improves our intellectual ability but it helps us gain skills and values which can help us to be useful in our society. Owing to this, Noan believes that "experts hardly disagree on the crucial role education plays in fighting under development" (quoted in Aghenta, 9). Aghenta further posits that "education brings about enlightenment, productivity, creativity, initiative, innovation, and inventiveness" (10). This implies that education is a total makeover of what we already have. Probing further, Onyemerekeya has the view that "education is an activity that goes on in a society, whether simple or complex, in which they attempt to develop their children's personalities as well as prepare them for effective membership of their societies" (1). This implies that education helps to improve our individual personality as it is a process of learning to live as a useful and acceptable member of the community to which one belongs (Farrant quoted in Onyemerekeya, 2).

This work attempts a discussion of Nollywood's advocacy of education for sustainable human development. The concept of development communication is adopted for conceptual foundation; while the theory of knowledge gap hypothesis is adopted for theoretical backing. The work gives a brief insight into Nollywood before reading Nollywood's advocacy of education for human development in selected films. The work concludes with some recommendations to the government, educational institutions, stake 
holders in education in Nigeria, Nollywood filmmakers and the general public.

\section{Knowledge Gap Hypothesis}

The knowledge gap hypothesis was first proposed in 1970 by three researchers of the University of Minnesota namely Phillip J. Tichenor, George A. Donohue, and Clarice N. Olien (Jeffres, Atkin and $\mathrm{Fu}, 30$ ). The knowledge gap hypothesis states that knowledge, is often differentially distributed throughout a social system just as it is with other forms of wealth. John Ojobor attempts to sum up the major postulations of the knowledge gap hypothesis this way:

This hypothesis posits that some group will acquire and make use of more knowledge than other groups...In individuals, the same concepts apply. There are information-rich people - those that possess the means of modern mass communication and use it. The informationpoor on the other hand, are those in the lower socioeconomic class whose education is poor and resources small. They... are not knowledgeable in areas that might lift them into success. While the information-rich are the 'haves', the information poor are the have-nots. These have-nots do not see any relationship between their problems and communication $(22-23)$ (added emphasis).

From the points of emphasis in the above view of Ojobor, the pride of place education occupy in the discussion of the knowledge gap hypothesis. With it, the information-poor can bridge the gap between them and the information-rich to the extent that they can completely close the gap and/or even topple the initially information-rich. 


\section{Development Communication}

The concept of development communication is a recent trend. Various names have been used to denote the concept but development communication and communication for development are more generally used. To Uwakwe (Development Communication, 45),

Development communication implies the adaptive use of the media (traditional or modern, or both) for the improvement of human lot; that is, the application of the media in the development in the overall matrix of human integration, human acceptance and human benefits.

Victor Kogah supplies a more simplified but precise definition of development communication. To him,

Development communication is a process, which involves a systematic approach or method of sending and receiving information aimed at the sustainable growth of the people. The above definition emphasises that development communication should be people-oriented and peoplecentred (163).

Development communication is one concept that can no longer be ignored in the present audio-visual friendly information and communication era.

\section{Sociology of Nollywood}

In this information and communication era, film has come to occupy a prominent position in our global village -the world. By its creation of the aura of reality through audio-visual means, film has a universal power of communication. According to Awaeze and Nworgu (37), "this powerful medium of light and sound takes its viewer to the realm of reality or believability." Onyeka 
Uwakwe affirms this by asserting authoritatively that over the decades, film has continued to grow as a significant mass medium of education and entertainment (Introduction to Mass Communication in the Digital Age, 96).

The Nigerian video film industry, Nollywood, has attracted a new wave of international interest since after the May 2009 UNESCO report analysis from which two issues where raised thus: "that Nollywood was now the second largest film industry in the world, and that it had achieved this feat from the bottom up, without the benefit of state assistance" (Bud, 91). From the vintage point of the early 1990s, Nigeria has evolved a film industry and this is the one she has: one that has meshed within its financial, production and distribution/marketing structures avant-garde and experimental elements derived from both the global film industry and from within the national milieu. Nollywood has carved out a niche for itself in many spheres of the Nigerian nation state. It projects "the Nigerian culture and indeed, the African continent to the outside world" (Ayakoroma, 2). Nollywood has offered much to the country politically, socially, educationally, morally, and most importantly, economically. Nollywood has been an advocate of adult education in Nigeria as can be seen in very many video films.

Mobilizing the uneducated, the poor and the underdeveloped to build a society that is self sufficient, we need to develop them. Many in this group have potentials yet untapped and when they fully develop will be of immense benefit not only to themselves but also to the nation at large. There cannot be meaningful development in modern society where majority of the populace is illiterate. This becomes obvious when viewed against the importance of education to improve standard of living. This makes 
adult education very important to fill in the gap of those that have missed the formal system of education. According to Ani (2003), "adult education is erroneously regarded as meaning adult literacy education only, by most people in Nigeria. Adult literacy education is part of adult education" (2) This implies that adult education can also be known as adult literacy education. According to Houle (1972)

Adult education is the process by which men and women seek to improve themselves seek to improve themselves or their society by increasing their skill, their knowledge, or their sensitiveness, any process by which individuals, groups or institutions try to help men and women improve in these ways (quoted in Chigbo, 17).

The inference from this is that adult education can be done informally and non-formally. To UNESCO (2)

Adult education is the entire body of organized educational process whatever the conten,t level and method, weather formal or otherwise, education in schools colleges and universities as well as in apprenticeship. Whereby persons regarded as adult by the society to which they belong, develop their abilities, enrich their knowledge, improve their technical or professional qualifications, or turn them in a new direction and bring about changes in their attitude or full personal development and independent social economic and cultural development (quoted in Wokocha, 10).

This implies that any term of adult education that a person embarks on, weather informal or non-formal, he/she must be purposive and geared towards achieving the target purpose(s). 


\section{Nollywood's Advocacy of Relevant Education for Sustainable Human Development in Nigeria: Reading Selected Films}

\section{The Illiterate Series}

The captivating movie was produced at a time Nollywood filmmakers were using different but related titles for sequel parts of a film. This film has three parts that were titled The Illiterate, Tears of the Illiterate and Joy of the Illiterate. It should be pointed out here that the trend now in the industry if to use the "season" tag for sequel parts of a film. In the film, Ikenna (Sylvester Madu), Ekene (Yul Edochie), and Ugo (Ken Erics) are three brothers who lost their parents at their very tender ages. Ugo, the last among the three brothers, had to leave school to engage in carpentry work to help train his other brothers even though he was very young and the last born in the family. Later on in the film, Ekene is able to travel aboard for greener pastures with the financial support of Ugo. There, he makes a lot of money which Ekene manages very well at home. On the other hand Ugo is doing very well in his carpentry work in the village.

On Ikenna's return to the country, he is able to bring his two brothers together in his house. The three brothers have the fiancées- Selina (Queeneth Hilbert), Monica (Eve Esien), and Adanma (Tonto Dike) respectively. Because Ugo and his fiancée, Adanma, are both illiterate, they were seen as not belonging to the class. Hence, Ekene and Ikenna, and especially Monica the fiancée to Ekene, maltreated Ugo and Adanma to the point of chasing them out of the house. Humbly, Ugo and Adanma resign to fate by leaving the house to continue their life independent of Ikenna and Ekene. Trouble ensues between Ikenna and Ekene through their fiancées. Monica is the brain behind the quarrel between the two 
brothers. Worse still, Ekene's fiancée steals Ikenna's money and car and abandons the house for long. When she eventually comes back after a very long time, Ekene did not bother to ask her about the stolen money and car. Rather he hugs her passionately and welcomes her back to the house. As the events of the film unfold, Ikenna is struck by a deadly sickness and is taken to a native doctor's place for treatment. Selina Ikenna's fiancée could not bear this. She absconds with Ikenna's money. Ikenna and Ekene are left with little if not nothing.

Mean while, Ugo wins 10 million naira contract which helped him start a new life. He is also convienced to enroll himself and Adanma into Adult education system. Ikenna and Ekenna are faced with severe hardship. Finally, the two brothers resolved to reconcile with Ugo. At the point of discovering Ugo, he is now a well educated man happily married to his pregnant wife Adanma who has also acquired western education and is now polished. They whole heartedly ask for forgiveness which they got from Ugo and Adanma.

As pointed out earlier, the movie was produced at a time Nollywood filmmakers were using different but related titles for sequel parts of a film. This film has three parts that were titled The Illiterate, Tears of the Illiterate and Joy of the Illiterate. In more recent time, Nollywood films are seasons are being used to part films.. In an oral interview, Richmond Ezihe of Rich Rock Productions gave more insight into this saying:

Having spent so much making a film, part of the strategy to recoup the money is to extend the story. Before now, we were using the parting system of changing the titles of 
sequel parts of our films. But people started complaining that this brought confusion. It brought confusion in the sense that the audience found it difficult to recognize the sequel arts of films. Sometimes, the audience does not know which title comes first before the other(s). So they may start with the ending art first. This also brought confusion. So we held a brain storming meeting and agreed to stick to one title. It was then that we decided to adopt the use of seasons in place of parts.

In this film, prevailing circumstances made Ugo to drop out of school even though he is the youngest of the three brothers. He found himself engaged in non- formal education - carpentry work. Though Ugo has not acquired formal education, he acquired informal education which made him gainfully employed and useful to the society at large. In this type of education, the aim is to acquire skills and knowledge "through on the job training" (Ani, 261). Ugo cannot be said to be without education; all he lacked is formal education. But "unfortunately, Nigerians do not regard informal education as a real or proper education because in many cases, certificates, diplomas, and degrees are not issued to authenticate it" (Ani, 261 - 262).

When Ikenna made it abroad, he comes back home and brings his siblings together. As time goes on, the challenge of lack of formal education is brought to the forefront. This is shown in the characters of Ugo and and his fiancée, Adanma, and through the ungrammatical English they speak and their inability to fit well into the society. Ugo and Adanma speak high level of ungrammatical English and Adanma could not even observe the simplest table manners and etiquette. Ikenna and Ekene could no 
longer bear the illiterate state of Ugo and most especially Adanma. They did not also attempt to enroll them into formal education. They started plotting for a way to send Adanma out of the family cycle. When Ekene adviced Ugo to send Adanma away he replied by saying "Adanma is a good girl, she wash my cloths and I can't send her away." Ekene was irritated by this response and he had this to say to Ugo: "Your problem is that you are illiterate, and you don't listen to instruction." This statement touched Ugo and he decided to report the case to their eldest brother Ikenna. Ikenna's response is captured in this line:

Ikenna: I was even thinking of telling you to tell that girl to stop coming here. I mean, I want you to stop seeing her. She is an illiterate for crying out loud. You need an educated girl, possibly a graduate, someone who you can learn with.

This line prompted Ugo to think of enrolling himself and Adanma in adult education programme. This part of the film tries to enlighten people who think that education is time bound to have a rethink. Even when Ugo informs his brothers of his plan to enroll himself and Adanma in adult education, they advised him that it is a waste of precious time and money. They never imagined that Ugo will one day be educated like, or even better than, them. When the situation became worse with Ugo and Adanma, Ugo insisted on enrolling into adult system of education but Ekene particularly saw it as a waste of time. Hear him:

Ekene: Listen to yourself. I have told you it will be a total waste of money you know, just like trying to bend 
a stick when it is dry rather than doing that when it is fresh. That is what it is.

Ugo did not let what Ekene his brother said to him to discourage him. The situation continued to get out of hand to the extent that in Ugo's absence, Adanma was sent out of the house very late in the night. When Ugo heard of it and complained, he was beaten up by his brothers. Hence, Ugo and Adaanma decided to leave the house to reside in Abuja for the simple reason of running away from the reach of his brothers. They were helped by Patrick (Prince Nwafor) who accommodated them. Patrick also uses his connection to secure a 10 million naira contract for Ugo which makes him to start living a decent life in Abuja. Patrick further helped Ugo by broadening his horizon and perception of life. He advices Ugo saying:

Patrick: Education is very important in one's life. You need to be educated.

This tallied with Ugo's earlier plans which his brothers killed. Ugo therefore enrolled himself and Adanma in an adult education programme where they started learning gradually. As time goes on Ugo and Adanma were able to learn. When finally the family reconciled, there was a celebration party. In that party, an opportunity presented itself for Ugo and Adanma to correct the mistakes they made during their illiterate state. They were able to speak correct English and Adanma was able to observe table manner. 


\section{Ekaette Goes to School}

In this film Selina (Ini Edo) is married to Onuwa (Bob Manuel Udokwu). Selina, who in the film hails from Akwa Ibom State, has Ekaette as her original name as given to her by her parents. Onuwa changes the name to Selina knowing that Ekaette will not be an acceptable name and that the name carries some negative connotations with it. Selina is known to always cause trouble in the village usually prompted her illiteracy. The villagers also get on her nerve by insulting and calling her names. Selina is disturbed by the fact that she is not educated because even her husband, Onuwa, insults her on account of this.

Selina takes the decision that she must enrol back to school. She pursues this with vigour and ends up starting school. She takes the pain to go to school every morning and on her way little kids will always mock with mockery songs. This did not deter her as she is determined to learn. As the film progresses, Selina gets pregnant and wants to abort the baby on the excuse that it will distract her from going to school but her husband Onuwa rejected the idea of aborting the pregnancy for his first child. Even with the stress of the pregnancy, Selina sits for WACE and passes with good grades. Selina can now read and write and even sign her husband's signature. An opportunity comes up in the community for someone in to be selected to represent the community. Selina, having passed her WACE is selected to be the village counsellor. The implication is that all the people who mocked her are now under her control especially the two girls, Angela and Nkechi, who later suffered hardships in the hands of their husbands.

The film maker used the film to highlight the inevitable place education occupy in human development and to encourage those 
who missed formal education at certain stage in life that they can still bridge the knowledge gap by going back to school. Selina was so mocked in the film mostly for her illiteracy and this makes her to fight. The height of the humiliation came when she could not sign her signature to pick her husband's parcel. To cover up for her inability to sign a signature, she pretended to be busy:

Delivery Man: Madam, you have to sign your name and your signature on this paper.

Selina: $\quad$ I de wash na, my hand dey wet. Make you help me sign am.

Delivery Man: Madam, if you can't sign this, am leaving with the parcel.

This gave Selina serious concern and she makes up her mind to go to school. Her husband's reaction to this decision is to as discourage her by reminding her that she has grown past school age. Insults, mocking songs or even pregnancy, could deter Selina from going to school. With her education at and advanced age, Ekaette/Selina was able to bridge the knowledge gap between her and her contemporaries, especially Angela and Nkechi, who went to school at their early stage of life. It must ne stated that if Selina continues with her schooling, she has the capacity to overtake them and be ahead of the in the information-rich class.

\section{The Adaure/Ada Mbano Series and Nkoli Nwa Nsukka}

The video film Adaure have as it sequel parts Ada Mbano, Ada Mbano Reloaded, Ada Mbano in Love, and Aunty Otuocha. With the advent of the season parting approach, the makers of the film have added Ada Mbano in London (Seasons 1 to 6). Again, the video film Nkoli Nwa Nsukka strictly followed the season approach 
and has seasons 17 and 18 at present. The two films, the Adaure/Ada Mbano series and the Nkoli Nwa Nsukka series, follow the trend in storyline set by The Illiterate series which has in it The Illiterate, Tears of the Illiterate, and Joy of the Illiterate. As earlier said, The Illiterate series presented the story of a naive and illiterate village girl, Adanma (Tonto Dike) who finds herself in the city. Her ignorance, incongruity and malapropism are the comic dimensions explored in the film.

The success of The Illiterate series in the experiment in this trend may have necessitated the other films in this line. The only difference is that while The Illiterate series is in English Language, the Adaure/Ada Mbano series and the Nkoli Nwa Nsukka series are both in Igbo Language but subtitled in English. Both films also explore the ignorance, incongruity and malapropism of the lead actors and further explore for their comic dimensions the undiluted dialects and speech mannerisms of their settings portrayed through the lead actors. The Adaure/Ada Mbano series explores the dialect and speech mannerisms of the Mbano people of the present day Imo State Nigeria while the Nkoli Nwa Nsukka series explores the dialect and speech mannerisms of the Nsukka people of the present day Enugu State.

These two films are used by the film makers to advocate for adult literacy for those who missed school in their tender years. In the Adaure/Ada Mbano series, Adaure/Kelly Queen Nwokoye) missed school in her tender years. When she eventually came to town, she made efforts to enrol into school. This is seen in the sequel part titled Ada Mbano Reloaded. It could be right to assert that with the upgrade in her education, Adaure/Kelly achieved human development that positively affected her life. In the Nkoli Nwa Nsukka series, the eponymous heroine, Nkolika, was not opportune 
to attend school during her school age due to poverty and general illiteracy in her community. When divine providence made it possible for her to get a loving and education loving husband, she was able to go back to school. This could be seen from the $5^{\text {th }}$ season of the film. She defied all shades of insult and abuses from the younger students to remain in school and graduate in flying colours. It could be rightly said that this educational attainment of Nkoli developed her personality and further equipped her for other professional roles (police, nurse, and pastor) she was to later play in the film.

\section{Conclusion}

The Nigerian video film industry, Nollywood, has continued to bring its sociological functions to bear in the Nigerian nation state. This work has tried to examine Nollywood's advocacy of education for human development through the reading of some video films. The above reading of the advocacy of adult literacy education in Nollywood is not by any means exhaustive. There are very many other Nollywood films that carry this same message, including Okon Goes to School and the Dumebi series. Yet, this work recommends that Nollywood filmmakers pay serious attention to salient message that may be contained in their films in other not to portray pictures that can do great disservice to educational advancements. The government in Nigeria, educational ministries, agencies and institutions, as well as other stakeholders in the education sector should partner Nollywood in preaching this educational message. This they can do through concept placement options. In concept placement, the corporate messages of government, her agencies and other legal organizations and institutions are inserted in films - usually interwoven into the plot of such films. Concept placement banks on the extraordinary 
power of film in mobilizing the masses, as well as the large number of people film reaches out to, to achieve its aim (Ihentuge, Embedded Marketing, 28 - 29).

The general public, particularly the academe, should see and explore the positive aspects of Nollywood rather than continue to treat the industry with contempt as was the case with the Onitsha market literature - the consequence of which we are still facing. Put in other words, pay some serious sociological attention to Nollywood and avoid, in the exact words of Onookome Okome, "the silly history of neglecting the production and consumption of popular culture in Nigeria and indeed Africa" (quoted in Ihentuge, The Way of Onitsha Market Literature, 642).

\section{Chisimdi Udoka Ihentuge}

Alvan Ikoku Federal College of

Education, Owerri

apparthy22ud@yahoo.com

\& Maudlyn Oghenesuvwe

Ejogharado

National Open University of

Nigeria, Benin City

ejogharadomaudlyn@gmail.com

\section{Works Cited}

Aghanta, J.A. "Educational Management as a strategy for National Development and Integration in Nigeria." Ebenebe R.C. \& Akudolu R.L. (Eds) Education for National Development and Integration. Awka: Faculty of Education, Nnamdi 
Azikiwe University Awka Anambra State, 2002: 7 - 20. Print.

Ani, R. O. "Non-Formal Adult Education Strategies for Improving National Development and Integration." Ebenebe R.C. \& Akudolu R.L. (Eds) Education for National Development and Integration. Awka: Faculty of Education, Nnamdi Azikiwe University Awka Anambra State, 2002: 260 - 268. Print.

Alkire, S. "Human Development: Definitions, Critiques, and Related Concepts." Background paper for the 2010 Human Development Report, Oxford Poverty \& Human Development Initiative (OPHI) Working Paper no. 36, 2010. Accessed January 10, 2016 from www.ophi.org.uk. Online.

Ani, R. O. "Non-Formal Adult Education Strategies for Improving National Development and Integration." Ebenebe R.C. \& Akudolu R.L. (Eds) Education for National Development and Integration. Awka: Faculty of Education, Nnamdi Azikiwe University Awka Anambra State, 2002: 260 - 268. Print.

Anugwom, E. E. "Theories of Social Conflict." Miriam IkejianiClark. (Ed) Peace Studies and Conflict Resolution in Nigeria: A Reader. Ibadan: Spectrum, 2009. 36-51. Print.

Awaeze, C.C. \& Nworgu, K.O. History of Motion Pictures and Film Criticism. K.O. Nworgu (Ed). Understanding mass Communication: Concepts and Applications. Umuguma, Owerri: Ultimate Books, 2011: Print.

Ayakoroma, B. F. "Trends in the Development of Nigerian Video Film Industry." Duro Oni \& Ahmed Yerima (Eds). Trends in the Theory and Practice of Theatre in Nigeria. Lagos: SONTA, 2008: 1-22. Print. 
Bud, Alexander. (2014). "The End of Nollywood's Guilded Age? Marketers, the State and the Struggle for Distribution." Critical African Studies, 6, 1: 91-121. Accessed October 10, 2015 from http://www.tandfonline.com/loi/rcaf20. Online.

Chigbo, M.A. "The History of the Role of Adult Education in Nigeria." Trumpeting Knowledge. A Journal of Adult Education Studies vol. 1 No.1. Akwa: Faculty of Education Nnamdi Azikiwe University Awka Anambra State, 1996: 7-22. Print.

European Historical Economics Society. Human Development in Africa: A Long- Run Perspective. EHES Working Papers in Economic History, No. 8, 2011 Accessed 20 ${ }^{\text {th }}$ February, 2016 from www.eehes.org/EHES No8.pdf. Online.

Ihentuge, C. U. "Embedded Marketing and the Quality-Quantity Dichotomy in Nollywood." The Creative Artist: Journal of Theatre and Media Studies, vol. 8, No. 3. Awka: Theatre Arts Department, Nnamdi Azikiwe University, Awka, 2014: 18 - 42. Print.

. . "The Way of Onitsha Market Literature: A Case for Proper Archiving of Nollywood Films." Journalism and Mass Communication vol. 4, No. 10. New York: David publishing Company, 2014: 640 - 650. Print.

Ivowi, U.M. "Keynote Address". Ebenebe R.C. \& Akudolu R.L. (Eds) Education for National Development and Integration. Awka: Faculty of Education, Nnamdi Azikiwe University Awka Anambra State, 2002: 1 - 6. Print.

Jeffres, L. W., Atkin, D. \& Fu, H. "Knowledge and the Knowledge Gap: Time to Reconceptualize the 'Content'." 
The Open Communication Journal, 5. 2011: 30-37. Accessed 10 April, 2016, from benthamopen.com. Online. Kerlinger, F. N. Foundations of Behavioural Research. New York: Holt, Rinehart and Winston, 1973. Print.

Kogah, V. "Development Communication: The Role of the Broadcast Media." Onyeka Uwakwe (Ed) Communication and National Development $\left(2^{\text {nd }}\right.$ ed) Enugu: Cecta Books, 2007: 160 - 171. Print.

Ojobor, Ifeanyi J. "Mass Communication Theories." Chinyere Stella Okunna (Ed) Teaching Mass Communication: A Multi-Dimensional Approach. Enugu: New Generation Books, 2002. 3 - 26. Print.

Onyemerekeya, C.C. "Meaning and Objectives of Education." Teacher Education in Nigeria. Owerri: Department of Curriculum Studies, Alvan Ikoku Federal of Education Owerri, Imo State, 2002: 1-8. Print.

Uwakwe, O. Introduction to Mass Communication in the Digital Age. Onitsha: Base 5 Publishers Ltd, 2010. Print.

... "Development Communication: An Analysis of the Rationale and Roles." Onyeka Uwakwe (Ed) Communication and National Development $\left(2^{\text {nd }}\right.$ ed) $\quad$ Enugu: Cecta Books, 2007: 45 - 61. Print.

Wokocha, A.M. "The Philosophical Perspective of Adult Education." Trumpeting Knowledge. A Journal of Adult Education Studies vol. 1 No.1. Awka: Faculty of Education Nnamdi Azikiwe University Awka Anambra State, 1996: 71-5. Print. 


\section{Videography}

Ekaette Goes to School: Dir. Mac Collins, Chidebe. With Ini Edo, Bob Manuel Udokwu and Rachael Okonkwo. Rockcelly Resources Films Ltd, 2014.

The Illiterate Series: Dir. Madu, Sylvester, With Ken Erics, Yul Edochie, Sylvester Madu, Queeneth Hilbert, Eve Esien and Tonto Dike. Bright Future Movies Production Ltd, 2012.

Adaure/Ada Mbano Series: Dir. Anyanji, Theodore. With Queen

Nwokoye, Mary Remmy, Sugar Chika Asoegwu, Chita Agu, Prince Nwafor and Vincent Opurum. Divine Touch Productions, 2012/2013/2014.

Nkoli Nwa Nsukka (Seasons 1 - 18): Dir. Mac-Collins Chidebe. With Racheal Okonkwo, Junior Pope Odonwodo, Princess Njideka Okeke and Browny Igboegbu. Great World Entertainment, 20014/2015. 